\title{
En kvinne i 30-årene med brystkreft og bilateral struma
}

\author{
Hos pasienter med symptomer fra ulike organsystemer vil ofte ulike \\ spesialister være involvert i behandlingen. En tverrfaglig tankegang \\ kan være helt avgjørende for tidlig diagnostikk og livreddende preven- \\ tive tiltak.
}

En kvinne i slutten av 30-årene ble innlagt elektivt med mistanke om et lokalavansert karsinom i høyre bryst. Av sykehistorien fremgikk det at hun hadde hatt diabetes mellitus type 1 fra 11-årsalderen og fått påvist et ekstra, ikke-fungerende nyreanlegg. Hun hadde vært utredet på lokalsykehus for bilateral struma med ultralyd og CT hals et par år tidligere. I disse undersøkelsene konkluderte man med kolloid knutestruma og hadde ingen malignitetsmistanke. Det finnes ingen informasjon om cytologi ble tatt. Pasienten hadde to barn. Flere av pasientens tanter og onkler på mors side av familien var døde av kreftsykdom.

Mistanken om et lokalavansert karsinom i høyre bryst kom etter en mammografiundersøkelse utført på et privat røntgeninstitutt. Pasienten var plaget av ømhet $i$ brystene og hadde bedt om undersøkelsen. Undersøkelsen av brystene og aksillene påviste malignitetssuspekte forandringer i høyre bryst, metastasesuspekte lymfeknuter i høyre aksille samt uspesifikke forandringer $i$ venstre bryst. Den radiologiske diagnosen ble ansett som sikker, og pasienten ble henvist direkte til innleggelse. Biopsier tatt i forbindelse med innleggelsen viste et duktalt mammakarsinom $i$ høyre bryst og lymfeknutemetastase $i$ høyre aksille.

Cytologisk prøve fra en radiologisk benignt preget lesjon $i$ venstre mamma viste papillære cellegrupper uten tegn til atypi. Biopsi ble ikke tatt fra denne lesjonen. Ny radiologisk utredning av thyreoidea viste et bilde forenlig med kolloid knutestruma, men cytologiske prøver inneholdt for lite materiale og var ikke diagnostiske. Pasienten fikk preoperativ cellegiftbehandling og mistet håret. Det viste seg å være vanskelig å finne en parykk som var stor nok til hennes hode. Syv måneder etter oppstart av cellegiftbehandlingen ble det utført ablatio av høyre bryst med påfølgende postoperativ strålebehandling.

Synkrone funn av tumorpregede forandringer i brystene og thyreoidealappene hos yngre personer er uvanlig. Ved funn av malign neoplasi $i$ et av disse organene vil det være viktig å avklare hvorvidt tumorer påvist $i$ det andre organet representerer metastase eller en ny primærtumor. Det kan få behandlingsmessige konsekvenser.

På grunn av trykksymptomer på halsen og respirasjonsubehag ble det utført en ny radiologisk vurdering av thyreoidea med cytologiske prøver, men heller ikke disse ga tilstrekkelig diagnostisk materiale. Pasientens venstre thyreoidealapp ble fjernet året etter at hun ble behandlet for kreft $i$ høyre bryst, uten at det forelå noen preoperativ cytologisk diagnose. Makroskopisk undersøkelse av venstre thyreoidealapp viste multiple tettliggende knuter (fig 1). Histologisk undersøkelse viste et uvanlig bilde med tettliggende follikulære adenomer og adenomatøse kolloide knuter (fig 2). De påviste forandringene samsvarer med funn som $i$ litteraturen er beskrevet som karakteristisk for Cowdens syndrom (CS), som er en dominant arvelig tilstand som blant annet karakteriseres av tallrike benigne og maligne neoplasier og hamartomer. Histologibesvarelsen indikerte at bildet kunne gi mistanke om Cowdens syndrom, og pasienten ble henvist til genetisk utredning. Samme år som venstre thyreoidealapp ble fjernet, ble det også fjernet et kavernøst hemangiom fra huden på venstre lår.

Fosfatase og tensin homolog-genet, PTEN, er et tumorsuppressorgen og har en sentral rolle i kontroll av celleproliferasjon, differensiering og apoptose (1). Mutasjon $i$ genet bidrar til økt cellulær proliferasjon, og somatiske mutasjoner $i$ PTEN-genet er assosiert med en rekke ulike typer kreft (2, 3). PTEN- hamartomtumorsyndromer (PHTS) er sjeldne, arvelige tilstander og skyldes kimbane mutasjoner i PTEN-genet. Tilstanden inkluderer Cowdens syndrom, Bannayan-Riley-Ruvalcaba syndrom (BRRS), Proteus syndrom eller Proteus-lignende syndromer og autismelignende syndromer assosiert med makrokefali (4).

Rundt to år etter at hun fikk påvist mammakarsinom kom pasienten i følge med sin mor til genetisk veiledning. Mor opplyste at pasienten hadde vært mye syk som barn. I

\author{
Eva Sigstad \\ ESP@ous-hf.no \\ Krystyna Kotanska Grøholt \\ Klinikk for diagnostikk og intervensjon \\ Avdeling for patologi \\ Oslo universitetssykehus

\section{Kjersti Jørgensen} \\ Astrid Stormorken \\ Seksjon for arvelig kreft \\ Avdeling for medisinsk genetikk \\ Oslo universitetssykehus \\ Henrik Stenwig Li \\ Hode- og halskirurgisk seksjon \\ $\emptyset$ re-, nese-, halsavdelingen \\ Klinikk for hode, hals og rekonstruktiv kirurgi
} Oslo universitetssykehus

Engelsk oversettelse på www.tidsskriftet.no 
løpet av barneårene ble det påvist nasale polypper, hun ble tonsillektomert og appendektomert, og det ble påvist diabetes mellitus. Mor fortalte at pasienten alltid hadde hatt et stort hode og at dette første gang ble registrert da pasienten var nyfødt. Pasienten ble kontrollert $i$ ett års tid for dette. Utredning i barneårene utelukket hydrocephalus som årsak til hennes økte hodeomkrets. Den økte hodeomkretsen kunne forklare hvorfor det $i$ forbindelse med cellegiftbehandlingen var vanskelig å finne en parykk som var stor nok til pasientens hode.

Det kom frem at pasienten hadde vært henvist til genetisk utredning 12-13 år tidligere på grunn av en opphopning av bryst-og eggstokkreft $i$ hennes mors familie. På det tidspunktet hadde ikke pasienten kreft. Hennes mor hadde heller ikke kreft, og det var ikke indikasjon for ytterligere genetisk utredning og gentesting. På denne tiden var gentesttilbudet relativt begrenset, og det forelå ikke tilbud om testing for mutasjon i PTEN-genet. Pasientens far døde da han var midt i 50-årene, men ikke av kreft.

I forbindelse med den genetiske veiledningen hun var henvist til med mistanke om Cowdens syndrom, ble det påvist hudmanifestasjoner som er karakteristiske ved PTEN-mutasjon (papillomer og trichilemmomer). Gentest viste en mutasjon i PTENgenet. Sammenholdt med det kliniske bildet passet dette med Cowdens syndrom.

Cowdens syndrom er en dominant arvelig tilstand som blant annet karakteriseres av tallrike hamartomer, som er overvekst av vevskomponenter som normalt skal være til stede i den aktuelle lokalisasjonen, i hud og slimhinner. Hudforandringene kan bestå av papillomer i munnslimhinne og på tunge, trichilemmomer, oftest lokalisert til ansiktet, særlig rundt nese, øyne og munn, og/eller fortykket hud på hender og føtter, såkalt akral keratose $(5,6)$. Det er også vanlig med hemangiomer, lipomer og nevrofibromer. Godartede forandringer i thyreoidea (kolloide knuter, adenomer), bryst (fibroadenomer, fibrocystiske forandringer) og tarm (hamartomer, ganglionevromer) er hyppig forekommende $(5,6)$. Nesten alle med Cowdens syndrom har hodeomkrets over 97,5prosentilen (7). Makrokefali ved Cowdens syndrom er sannsynlig sekundær til megencephalus (7). Mange med syndromet har lærevansker, noen har redusert mental kapasitet og også motoriske forandringer. Den individuelle variasjonen er stor $(5,6)$.

Det er en betydelig forhøyet kreftrisiko, der brystkreft, kreft i thyreoidea, livmorkreft og nyrekreft er de hyppigst forekommende kreftformene (8).

Det er vanlig å anta at flere enn $90 \%$ av personene som har Cowdens syndrom frem-

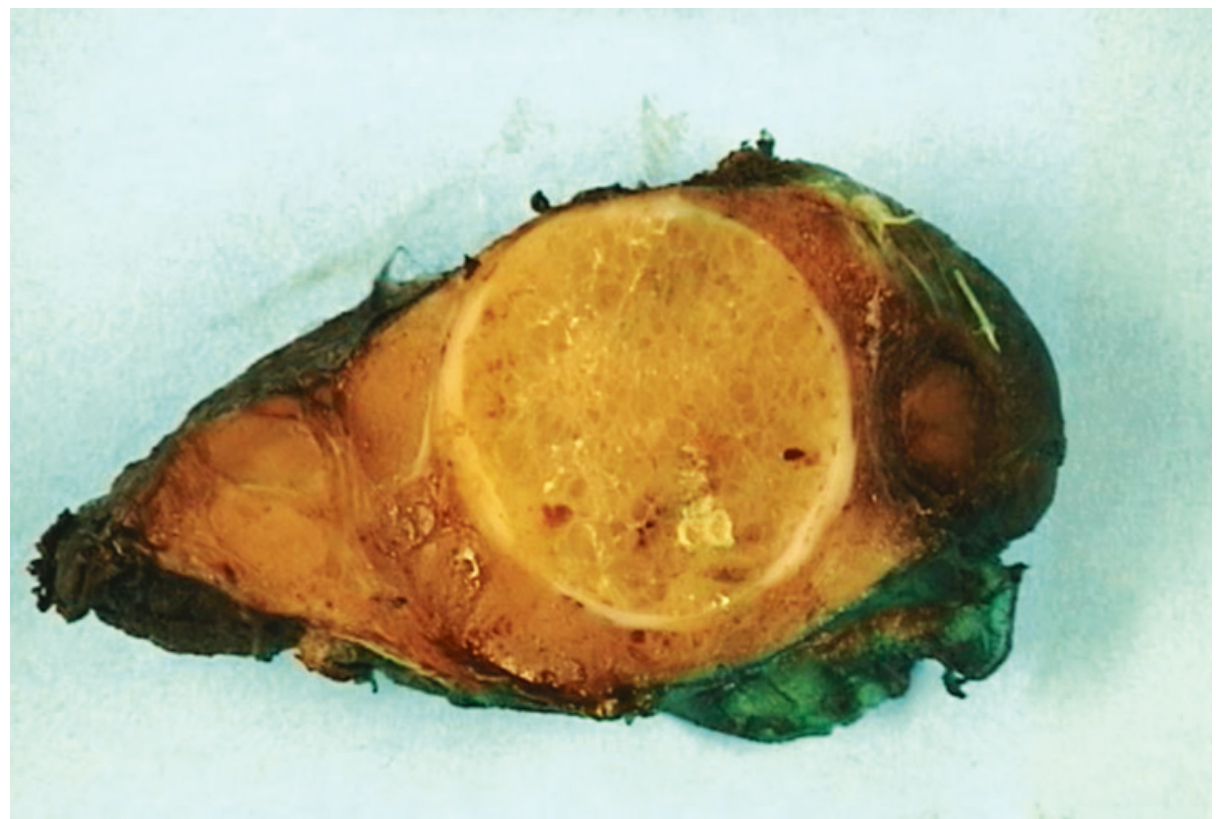

Figur 1 Bilde (makroskopisk) fra venstre thyreoidealapp med en stor og flere mindre knuter. Begge foto: Krystyna Kotanska Grøholt

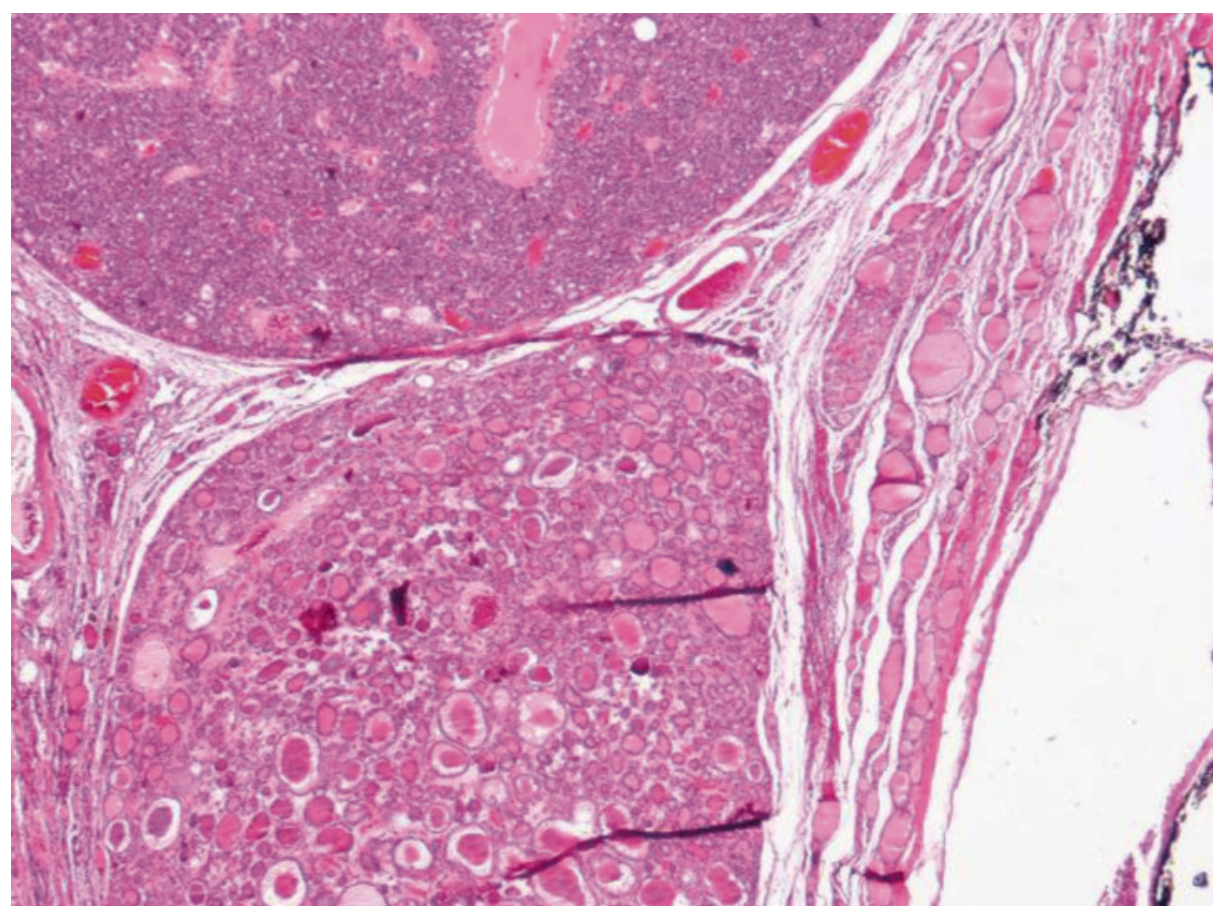

Figur 2 Bilde (mikroskopisk) fra venstre thyreoidealapp med to tettliggende follikulære adenomer

står med fenotypen i 20-årsalderen. De diagnostiske kriteriene for syndromet er blitt revidert flere ganger $(6,9)$ (ramme 1).

Det ble gjort videre genetiske undersøkelser i familien. Pasientens mor ble testet, men hun hadde ikke genfeilen $i$ PTEN-genet. På grunn av opphopning av bryst- og eggstokkreft i mors familie ble det også gjort analyse av BRCA1- og BRCA2- genene, som ikke viste mutasjon. Det kan ikke utelukkes at PTEN-genfeilen kom fra pasientens avdøde far. Alternativt var den nyoppstått hos pasienten.

Etter utredning hos medisinsk genetiker ble pasienten henvist til utredning av gjenværende venstre bryst. Det var da gått to år etter at karsinom ble diagnostisert $i$ høyre bryst. MR-undersøkelse av venstre bryst påviste en malignitetssuspekt lesjon, biopsi viste infiltrerende duktalt karsinom, og pasienten ble operert med ablatio av venstre 


\section{RAMME 1}

\section{Kliniske kriterier ved Cowdens syndrom}

Pasienten må fylle $\geq 3$ hovedkriterier hvorav et må være makrocephalus, LhermitteDuclos sykdom eller gastrointestinale hamartomer, alternativt to hovedkriterier og tre bikriterier. Rammen er modifisert fra Pilarski og medarbeidere (6)

\section{Hovedkriterier}

Brystkreft

Endometriekreft, epitelial

Thyroideakreft, follikulær

Gastrointestinale hamartomer, inkl.ganglionevromer, ekskl. hyperplastiske polypper, $\geq 3$

Lhermitte-Duclos sykdom, voksen

Makrocephalus, $\geq 97$-prosentilen: $58 \mathrm{~cm}$

for kvinner, $60 \mathrm{~cm}$ for menn

Makulær pigmentering av glans penis

Multiple mukokutane lesjoner:

Multiple trichilemmomer $(\geq 3$, minst en verifisert ved biopsil

Multiple palmoplantare keratoser $(\geq 3)$

Mukokutane nevromer $(\geq 3)$

Orale papillomer $(\geq 3)$

\section{Bikriterier}

Autismelignende syndrom

Tarmkreft

$\emptyset$ sofageal glykogen akantose $(\geq 3)$

Lipomer ( $\geq 3)$

Mental retardasjon (IQ $\leq 75)$

Nyrecellekarsinom

Testikulær lipomatose

Thyroideakreft, papillær eller follikulær Andre thyroidealesjoner, f.eks. adenomer, knutestruma

Vaskulære anomalier

bryst. Parallelt med påvisningen av mammakarsinomet $i$ venstre bryst ble det ved fornyet ultralyd av høyre thyreoidealapp funnet multiple, til dels store og uavklarte knuter. Cytologisk prøvetaking fra en liten knute $i$ høyre thyreoidealapp viste et cellebilde forenlig med en kolloid knute, mens materialet fra en stor knute ikke var diagnostisk. Med bakgrunn $i$ økende trykksymptomer og ubehag på halsen ble gjenværende høyre thyreoidealapp fjernet få måneder etter ablatio av venstre bryst. Histologien av høyre thyreoidealapp viste et $90 \mathrm{~mm}$ stort follikulært adenom og flere adenomatøse kolloide knuter, samsvarende med funn $i$ venstre thyreoidealapp.

MR- og CT-undersøkelser av pasienten senere samme år viste forandringer forenlig med skjelettmetastaser i columna og bekken samt multiple små forandringer forenlig med lungemetastaser. Klinisk ble disse forandringene oppfattet som spredning fra pasientens mammakarsinom, og det ble startet cellegiftbehandling. Pasienten er i live og får jevnlig oppfølging og behandling.

\section{Diskusjon}

Cowdens syndrom fikk sitt navn fra Rachel Cowden, den første pasienten som ble beskrevet med mange av de karakteristiske forandringene som påvises i denne pasientgruppen (10). Cowdens syndrom er sjeldent. En nederlandsk klinisk epidemiologisk studie fra 1999 har estimert prevalensen til å være mellom 1:200 000 og 1:250 000 (11), men da syndromet har et variabelt klinisk uttrykk og ofte er vanskelig å gjenkjenne, antas dette å være en underestimering (9). Et økt tilbud om gentester kan bidra til å avklare hvor hyppig sykdommen er, også hos dem som ikke fyller de klassiske kliniske kriteriene. Det er anslått at $10-47 \%$ av personer med PTEN-mutasjon har en de novomutasjon (12), det vil si at ingen av pasientens foreldre har mutasjonen.

Den store variasjonen i kliniske uttrykksformer av Cowdens syndrom gjør det utfordrende å stille diagnosen. Ikke alle pasienter med påvist genfeil i PTEN-genet oppfyller de kliniske kriteriene for syndromet, og tilsvarende kan det være pasienter som fyller de kliniske kriteriene for Cowdens syndrom, men som ikke har påvist mutasjon i PTEN-genet (13). Mange karakteristika for Cowdens syndrom er subtile og hyppig forekommende i den generelle befolkningen. Kliniske funn i ulike organer som hud, thyreoidea, bryst, tarm, sentralnervesystem og bløtvev, inkludert kar og urogenitalsystemet, gjør at pasienten blir ivaretatt av leger innenfor ulike spesialiteter med risiko for ikke å se sammenhengen. Ofte vil hudlegene være de første som møter pasienter med syndromet $(14,15)$. Påvisning av en $P T E N$-mutasjon vil gjøre det mulig å behandle premaligne tilstander og dermed bedre overlevelsen. Pasientens slektninger (foreldre, søsken og barn) bør tilbys gentesting. Barn med PTEN-genfeil kan i sjeldne tilfeller utvikle kreft i tillegg til godartede knuter i skjoldbruskkjertelen (8). Derfor er det tillatt å teste barn for dette. Ved funn av multiple hud- og slimhinnepapler hos unge pasienter bør Cowdens syndrom utelukkes. Også bryst- og endokrinkirurger som behandler både bryst- og thyreoidealesjoner, bør tenke på Cowdens syndrom som en diagnostisk mulighet.

Patologene har en sentral og viktig rolle i å avdekke syndromet (16). Nye og bedre patologidatabaser med en samlet oversikt over alle preparatene som er sendt til undersøkelse fra hver enkelt pasient, har gitt patologene et viktig diagnostisk hjelpemiddel til å

\section{RAMME 2}

\section{Anbefalte kontroller}

Rammen er modifisert fra Tan og medarbeidere og Gammon og medarbeidere $(8,13)$

Årlig ultralyd av skjoldbruskkjertel er sjelden aktuelt før tiårsalder. Profylaktisk tyreoidektomi kan vurderes dersom det er vanskelig å vurdere kjertelen på grunn av mye kuler.

Årlig mammografi og MR-undersøkelse av brystene fra 25 år. Profylaktisk mastektomi bør vurderes.

Årlig livmorkontroll med ultralyd og eventuelt prøver fra livmorslimhinnen fra 30 år.

Basis hudundersøkelse etter gentest. Kontroll ved behov eller ca. hvert femte år.

Årlig ultralyd av nyre fra 40 år.

Kolonoskopi hvert femte år fra 40 år.

identifisere pasienter som bør utredes for PTEN-mutasjon. Histopatologisk bør funn av et stort antall tettliggende follikulære adenomer og adenomatøse kolloide knuter medføre anmerkning $\mathrm{i}$ besvarelsen med en oppfordring til kliniker om å vurdere henvisning til genetisk utredning med hensyn til Cowdens syndrom. Pasienter som får påvist PTEN-mutasjon, blir anbefalt oppfølging med tanke på å forebygge maligne svulster eller å oppdage svulstene på et tidlig stadium. Retningslinjer for oppfølging har endret seg over tid og varierer noe mellom ulike institusjoner. De siste par årene har vi etablert retningslinjer på bakgrunn av det $(8,13)$ (ramme 2).

Pasienten som er presentert i denne kasuistikken hadde i flere år sammensatte kliniske symptomer og funn, men uten at disse ga mistanke om en genetisk sammenheng. Patologene reagerte på det histologiske bildet $\mathrm{i}$ thyreoideapreparatet, noe som førte til at pasienten ble henvist til gentesting. Kunnskapen om, og søkelyset på Cowdens syndrom, har vært økende internasjonalt og nasjonalt de siste ti årene, ikke minst som et resultat av stadig bedre tverrfaglig samarbeid. Pasienten i denne kasuistikken fikk sine første symptomer mange år før det var etablert diagnostiske kriterier og oppfølging av denne sjeldne sykdommen. I handlingsprogrammene fra den aktuelle tidsperioden da pasienten fikk påvist brystkreft, var Cowdens syndrom ikke nevnt. Etter dagens handlingsprogram for brystkreft skulle pasienten ha vært henvist til genetisk utredning. Etter at histologiske funn hos den aktuelle pasienten førte til genetisk utredning og påvisning av $P T E N$-mutasjon, er flere pa- 
sienter med PTEN-mutasjon avdekket ved Avdeling for patologi, Oslo universitetssykehus, etter påvisning av et karakteristisk histologisk bilde i thyreoideapreparater.

Da den aktuelle pasienten, på bakgrunn av familiehistorien, ble henvist til genetisk utredning 12-13 år tidligere, hadde hun ennå ikke fătt påvist kreft. Dette sammenholdt med at testtilbudet på den tiden var begrenset, gjorde at det ikke var indikasjon for ytterligere genetisk utredning. En tidlig mistanke om Cowdens syndrom hos en eller flere av klinikerne som hadde pasienten til behandling med påfølgende genetisk testing, kunne hos denne pasienten muligens ha ført til forebygging eller tidligere diagnostikk av hennes mammakarsinomer.

Denne kasuistikken viser at tverrfaglig samarbeid omkring pasienter med sammensatte symptomer og funn er viktig. Tverrfaglige møter der sykehistorie, symptomer, kliniske funn, radiologiske funn og patologifunn blir presentert og diskutert, vil kunne bidra til at syndromer av typen Cowdens syndrom blir avdekket så tidlig at profylaktiske tiltak kan iverksettes.

Pasienten har gitt samtykke til at artikkelen blir publisert.

\section{Eva Sigstad (f. 1966)}

er spesialist i patologi med spesialkompetanse i thyreoideapatologi.

Forfatter har fylt ut ICMJE-skjemaet og oppgir ingen interessekonflikter.

\section{Krystyna Kotanska Grøholt (f. 1954)}

er spesialist i patologi med spesialkompetanse i thyreoideapatologi.

Forfatter har fylt ut ICMJE-skjemaet og oppgir ingen interessekonflikter.

\section{Kjersti Jørgensen (f. 1972)}

er genetisk veileder.

Forfatter har fylt ut ICMJE-skjemaet og oppgir ingen interessekonflikter.

\section{Astrid Stormorken (f. 1959)}

er spesialist i medisinsk genetikk.

Forfatter har fylt ut ICMJE-skjemaet og oppgir ingen interessekonflikter.

\section{Henrik Stenwig Li (f. 1971)}

er spesialist i øre-nese-hals-sykdommer.

Forfatter har fylt ut ICMJE-skjemaet og oppgir ingen interessekonflikter.

\section{Litteratur}

1. Liaw D, Marsh DJ, Li J et al. Germline mutations of the PTEN gene in Cowden disease, an inherited breast and thyroid cancer syndrome. Nat Genet 1997; 16: 64-7

2. Gimm O, Attié-Bitach T, Lees JA et al. Expression of the PTEN tumour suppressor protein during human development. Hum Mol Genet 2000; 9 : 1633-9.

3. Song MS, Salmena L, Pandolfi PP. The functions and regulation of the PTEN tumour suppressor. Nat Rev Mol Cell Biol 2012: 13: 283-96.

4. Zbuk KM, Eng C. Cancer phenomics: RET and PTEN as illustrative models. Nat Rev Cancer 2007 7: $35-45$

5. Mester J. Eng C. When overgrowth bumps into cancer: the PTEN-opathies. Am J Med Genet C Semin Med Genet 2013; 163C: 114-21.
6. Pilarski R, Burt R, Kohlman W et al. Cowden syndrome and the PTEN hamartoma tumor syndrome: systematic review and revised diagnostic criteria. J Natl Cancer Inst 2013; 105: 1607-16.

7. Mester JL, Tilot AK, Rybicki LA et al. Analysis of prevalence and degree of macrocephaly in patients with germline PTEN mutations and of brain weigh in Pten knock-in murine model. Eur J Hum Genet 2011; 19: 763-8.

8. Tan MH, Mester JL, Ngeow J et al. Lifetime cance risks in individuals with germline PTEN mutations. Clin Cancer Res 2012: 18: 400-7.

9. Eng C. Will the real Cowden syndrome please stand up: revised diagnostic criteria. J Med Genet 2000; 37: 828-30.

10. Lloyd KM 2nd, Dennis M. Cowden's disease. A possible new symptom complex with multiple system involvement. Ann Intern Med 1963; 58: 136-42.

11. Nelen MR, Kremer H, Konings IB et al. Novel PTEN mutations in patients with Cowden disease: absence of clear genotype-phenotype correlations. Eur J Hum Genet 1999; 7: 267-73.

12. Mester J, Eng C. Estimate of de novo mutation frequency in probands with PTEN hamartoma tumor syndrome Genet Med 2012: 14: 819-22.

13. Gammon A, Jasperson K, Champine M. Genetic basis of Cowden syndrome and its implications for clinical practice and risk management. Appl Clin Genet 2016; 9: 83-92.

14. Mørk C, Gabrielsen TO. Cowdens sykdom. Syndrom med multiple hamartomer og neoplasier. Tidsskr Nor Lægeforen 1991; 111: 2432-4.

15. Skytte AB, Bojesen A, Bygum A. Cowdens syndrom diagnosticeret hos patienter med store hoveder, falske vorter og struma. Ugeskr Laeger 2014; 176 $165-7$

16. Nosé V. Thyroid cancer of follicular cell origin in inherited tumor syndromes. Adv Anat Pathol 2010; 17: $428-36$

Mottatt 29.6. 2016, første revisjon innsendt 29.12 2016, godkjent 18.4. 2017. Redaktør: Lars Frich 